\title{
Effects on Berry Shrinkage in Vitis vinifera. L cv. 'Merlot' From Changes in Canopy/Root Ratio: A Preliminary Approach
}

\author{
G. Gutiérrez-Gamboa, C. Pardo, Y. Moreno-Simunovic* \\ Centro Tecnológico de la Vid y el Vino, Facultad de Ciencias Agrarias, Universidad de Talca, Av. Lircay S/N, Talca, Chile.
}

Submitted for publication: March 2018

Accepted for publication: August 2018

Keywords: Berry shrinkage, berry shrivelling, canopy/root ratio, Vitis vinifera. L cv. 'Merlot', water relations

\begin{abstract}
A trial was conducted to find a possible relationship between the canopy/root ratio and the incidence and severity of premature berry shrinkage, and to propose an alternative to avoid this phenomenon in 'Merlot' grapevines. The ratio was changed by cutting foliage at a certain height $\mathbf{1 5}$ days before véraison, and by delaying the removal of trunk shoots. Treatments were the control (T1), $50 \%$ foliage area of control (T2), $75 \%$ foliage area of control (T3), and delayed trunk shoot removal (T4). Foliage area and the canopy/ root ratio were lower in the $\mathrm{T} 2$ and $\mathrm{T} 3$ treatments. $\mathrm{T} 4$ was ineffective in changing the parameters. The incidence of berry shrinkage was lower for the T2 and T3 treatments, with the percentage of affected plants dropping from the $\mathbf{5 2 \%}$ of the control to $\mathbf{2 2 . 9 \%}$ and $\mathbf{3 1 . 3 \%}$ for T2 and T3 respectively, and from $52.4 \%$ of the affected bunches to $16.6 \%$ and $21.2 \%$ for the same treatments respectively. The percentage of affected bunches falling into the range of moderate to severe damage fell from the $24 \%$ of the control to $5.2 \%$ and $3.9 \%$ for $\mathrm{T} 2$ and $\mathrm{T} 3$ respectively. Therefore, it is possible to avoid the incidence and severity of berry shrinkage by decreasing the canopy/root ratio in 'Merlot' grapevines.
\end{abstract}

\section{INTRODUCTION}

For many years, 'Merlot' and 'Carménère' cultivars were confused in Chilean vineyards, so that, when a distinction was made between them in the 1990 s, the viticultural behaviour in the vineyard of each of them became clear. In this way, it was observed that, in much of the 'Merlot' vineyards, berry shrinkage occurred, which affects the yield and wine quality at harvest (Moreno \& Vallarino, 2011). On the other hand, the growth curve of the grape berry (Vitis vinifera L.) has a double sigmoid shape, with two periods of significant growth being observed. The first one falls between fruit set and véraison, and the second one between véraison and maturity (Mathews et al., 1987; Coombe, 1992; McCarthy, 1997; Rogiers et al., 2000). However, in this second phase of grape berry development, when the concentration of sugars is still too low to harvest, a rapid loss of weight can be registered, causing berry shrinkage. This phenomenon has been described in Vitis vinifera. L cv. 'Syrah' (McCarthy, 1997; Rogiers et al., 2000, 2001; Carlomagno et al., 2018), where yield losses are estimated at around $25 \%$ of the total production (Rogiers et al., 2000; Krasnow et al., 2010).

Currently, publications on the subject are from the perspective of the damage to the conductive vessels that supply the grape berries. Some authors conclude that the premature dehydration of berries could be due to damage to the xylem inside the berry after véraison, a phenomenon that has been described in cultivars such as 'Riesling', 'Merlot', 'Muscat Gordo Blanco', 'Pinot Noir' and 'Syrah' (Düring et al., 1987; Findlay et al., 1987; Creasy \& Lombard, 1993; Rogiers et al., 2001). Others authors have reported that this phenomenon could be due to the fact that sugar accumulation in the berry apoplast may lead to the decline in xylem water influx during ripening, causing berry dehydration (Keller et al., 2006, 2015). Then there also are authors who showed the presence of phytoplamas in grapevines affected with the berry shrinkage phenomenon (Matus et al., 2008).

On the other hand, an inverse relationship between the daily gain in weight by the grape berries and the evaporative demand of the environment, even in berries close to harvest, has been reported (Rogiers et al., 2000). Water potential becomes more negative when the absorption of water is slower than transpiration. Thus, excessive transpiration, low absorption or both can lead to a water deficit in the plant (Tardieu \& Parent, 2017). It therefore could be expected that plants that possess a large surface area of leaves transpiring and a small number of roots supplying them (high canopy/ root ratio) have a lower water potential and therefore extract more water from the fruit. In this way, there could be a balance between the leaf area and the roots of a plant that ensures that it does not lower its water potential too much in the face of a high evaporative demand from the environment. Due to this, the aim of this work was to provide an alternative through a preliminary approach to avoid berry shrinkage in 'Merlot' grapevines by making changes in the canopy/root ratio in one study season. 


\section{MATERIALS AND METHODS Study site}

The field study was conducted in a commercial vineyard cv. 'Merlot' (from a local massal selection) of six years old, located in Los Niches-Curicó, Maule Valley, Chile (35 $05^{\prime}$ S.L., $71^{\circ} 03^{\prime}$ O.L.). The vineyard was planted at a distance of $2.5 \mathrm{~m}$ between rows and $0.9 \mathrm{~m}$ between plants, with rows oriented from north to south. Grapevines were trained to a vertical shoot positioned (VSP) trellis system and pruned according to the Guyot system, leaving about 20 to 22 buds per vine. The vineyard has drip irrigation, with an output per plant of $4 \mathrm{~L} / \mathrm{hr}$. The climate is sub-humid Mediterranean type, with a prolonged dry season with an average annual temperature of $12.7^{\circ} \mathrm{C}$, annual rainfall of $953 \mathrm{~mm}$, and potential annual evapotranspiration of $921 \mathrm{~mm}$. During the six warmest months (October to March), an average temperature of $16.5^{\circ} \mathrm{C}$ was registered, with a thermal sum of 1030 degree days and a relative humidity of $73 \%$, while the rainfall for the period from December to February was $33 \mathrm{~mm}$. The soil corresponds to the series Huecán (Mollisol), which is deep, of colluvial origin, with good drainage and silty clay loam (clay $27.4 \%$, sand $35.3 \%$, lime $37.3 \%$, organic matter $3.72 \%$, bulk density $1.26 \%$, field capacity $33.5 \%$, and a permanent wilting point of $16.7 \%$ ). The water provided for the period from véraison to harvest was $1115 \mathrm{~m}^{3} /$ ha. During the season, the vineyard presented premature dehydration of berries, causing losses of approximately $80 \%$, leaving some sectors more affected without harvesting.

\section{Grapevine treatments}

The field trial involved a comparison of the incidence of berry shrinkage in treatments with different canopy/root ratios from véraison to harvest, for which this relationship was altered by the direct reduction of leaf area or by delayed trunk shoot removal (Table 1). Foliage was cut approximately 15 days before véraison, so that the plants already showed very little or no growth of shoots. Before performing T2 and T3, the leaf area of 30 representative shoots was measured with a leaf area meter (model LI-3100, LI-COR, Lincoln, $\mathrm{NE}$ ), establishing the average contribution of each bud to the total leaf area of the grapevine and, subsequently, the cutting height required to leave $50 \%$ and $75 \%$ of the original foliar area for the T2 and T3 treatments respectively was calculated. Delayed trunk shoot removal was carried out when the shoots reached $1 \mathrm{~m}$ average length. The assumption was made that the root system remains the same for all treatments during the critical period when berry shrinkage occurs, since from the stage at which the treatments were established until 70 days later, there would not have been any

TABLE 1

Description of the treatments, Los Niches-Curicó.

\begin{tabular}{ll}
\hline Treatment & Description \\
\hline T1 & Control \\
T2 & Defoliation at $50 \%$ leaf area of control \\
T3 & Defoliation at $25 \%$ leaf area of control \\
T4 & Delayed trunk shoot removal \\
\hline
\end{tabular}

important development of the roots (McKenry, 1984; Van Zyl, 1984). The field trial was conducted in a homogeneous sector. The statistical design corresponded to random blocks with six repetitions, and blocking was done according to the proximity to a drainage channel. Each experimental unit consisted of 12 plants.

\section{Grape berry measurement}

From 30 days before véraison, the berry diameter was measured once a week until harvest. For this purpose, 18 berries were collected from two homogeneous grapevines. Once a week, 36 berries were collected from two homogeneous grapevines. Soluble solids were measured on seven dates, while $\mathrm{pH}$ and titratable acidity were measured three times in the obtained musts. The evolution of the incidence of berry shrinkage was evaluated once a week in 10 previously marked clusters from five grapevines per repetition, while at harvest, clusters from eight plants were evaluated per repetition. The incidence of berry shrinkage was expressed as the percentage of affected grapevines and clusters, and the severity was established by classifying each cluster according to the percentage of affected berries. Four categories were used: 1 ) healthy cluster: $0 \%$ affected berries; 2) slight damage: $1 \%$ to $32 \%$ affected berries; 3 ) moderate damage: $33 \%$ to $65 \%$ affected berries; 4) severe damage: $66 \%$ to $100 \%$ affected berries.

\section{Stem water potential $\left(\Psi_{\text {stem }}\right)$ and soil humidity measurements}

$\Psi_{\text {stem }}$ was measured six times until harvest: 1) post-flowering, 2) immediately before establishing $T 2$ and $T 3,3) 10$ days after establishing the treatments, 4) at véraison, 5) pre-harvest and 6) harvest, using a pressure chamber (Soil Moisture Equipment Corp, Santa Barbara, U.S.A.) according to the method described by Acevedo-Opazo et al. (2013). The moisture content of the soil was determined using a TDR (Soil Moisture Equipment Corp., Santa Barbara, U.S.A.), on the same dates that the stem water potential was measured.

\section{Canopy and root measurements}

After harvest, the total leaf area of one vine was measured, in duplicate. From each leaf, the pedicel was removed, after which the leaf area was measured with a leaf area meter (LI-3100, LI-COR, Lincoln NE, U.S.A.). Subsequently, a root count was carried out according to the methodology of Hunter and Le Roux (1992). The roots were classified into five groups according to the classification of Richards (1983): fine $(<1 \mathrm{~mm})$, extended (1 to $2 \mathrm{~mm})$, permanent (2 to $5 \mathrm{~mm}$ ) and structural ( 5 to $10 \mathrm{~mm}$ and $>10 \mathrm{~mm}$ ). Canopy/ root ratio was calculated by dividing the leaf area of the grapevine by its number of roots with a diameter equal to or less than $2 \mathrm{~mm}$ in the depth under the influence of the dropper $(60 \mathrm{~cm})$.

\section{Statistical analysis}

The statistical analysis of the parameters analysed was performed using variance analysis (one-way ANOVA) (Statgraphics Centurion XVI.I, Warrenton VA, U.S.A.). Differences between samples were compared using the Duncan test at a $95 \%$ probability level. 


\section{RESULTS AND DISCUSSION}

Canopy/root ratio and stem water potential (Ystem)

Foliar reduction gave rise to final differences in foliar area per grapevine between treatments with and without defoliation. However, no differences were found between $50 \%$ foliage area of control (T2) and 75\% foliage area of control (T3), resulting in $58 \%$ and $67 \%$ of leaf area with respect to the control (T1) respectively. The T2 and T3 treatments decreased the canopy/root ratio. Thus, comparing leaf area obtained, differences were found in canopy/root ratio between the control and the defoliation treatments (T2 and T3), without finding differences between the latter two (Table 2). At seven days after defoliation, stem water potential $\left(\Psi_{\text {stem }}\right)$ was higher in the T2 and T3 treatments compared to T1 and delayed trunk shoot removal (T4), which indicates that these grapevines (with a lower canopy/root ratio) are able to respond better to the evaporative demand of the environment (Table 3). These changes in $\Psi_{\text {stem }}$ imply that the canopy/root ratio is able to determine a change in the water status of the grapevine. This result matches those reported by Reynolds et al. (1996), who compared the grapevine water potential of different canopy/root relationships. It has been reported that the physiological and morphological alteration of plants under partial root-zone irrigation may bring more benefits to crops than improved water-use efficiency where carbon redistribution among organs is crucial in the determination of the quantity and quality of the products (Kang \& Zhang,
2004).

Although there were no extreme water potentials, reaching only $-0.6 \mathrm{MPa}$ close to harvest in the control grapevines, it is possible to think that, under an extremely high evaporative demand of the environment and with low soil moisture, a grapevine with a low canopy/root ratio should have a less negative water potential and therefore extract less water from the grape berries. Increased transpiration and decreased phloem influx have been suggested as causes for berry shrinkage (McCarthy \& Coombe, 1999; Rogiers et al., 2006). However, certain authors have provided clearly evidence that several varieties of grape berries remain hydraulically connected to the parent grapevine (Bondada et al., 2005; Chatelet et al., 2008), and therefore may lose water back to the parent grapevine late in ripening, as well as to the dry ambient air (Tyerman et al., 2004; Keller et al., 2008; Krasnow et al., 2010). Although the total leaf area of the treatments was very different from each other, which could have conditioned different water consumption between them, there were no differences in the moisture content of the soil between the treatments during the experiment (Table 3 ). This could be explained by the different water status of the treatments, where it is possible that the treatments with lower water potential could have closed their stomata for longer periods during the day to avoid gas exchange compare to the others treatments.

TABLE 2

Foliar area $\left(\mathrm{cm}^{2}\right)$, foliar area per gram of fruit $\left(\mathrm{cm}^{2} / \mathrm{g}\right)$, percentage of effective foliar area of the control (\%), and canopy/root relation (leaf $\mathrm{cm}^{2} / \mathrm{No}$. of roots thinner than $2 \mathrm{~mm}$ in the first $60 \mathrm{~cm}$ ): Post-harvest measurements, Los Niches-Curicó.

\begin{tabular}{|c|c|c|c|c|}
\hline Treatment & Foliar area $\mathrm{cm}^{2} /$ vine & $\mathrm{cm}^{2}$ leaf/g fruit & $\begin{array}{c}\% \text { of effective } \\
\text { foliar area } \\
\text { of control } \\
\end{array}$ & $\begin{array}{c}\text { Canopy/root ratio } \\
\left(\mathrm{cm}^{2} \text { leaf } / \mathrm{No} . \text { roots }<2\right. \\
\text { mm, } 60 \mathrm{~cm} \text { depth })\end{array}$ \\
\hline T1: Control & $43.224 \mathrm{a}$ & 16.5 & 100.0 & $117.6 \mathrm{a}$ \\
\hline $\mathrm{T} 2$ : Defoliation at $50 \%$ of $\mathrm{T} 1$ & $25.132 b$ & 8.9 & 58.1 & $70.4 \mathrm{c}$ \\
\hline T3: Defoliation at $75 \%$ of $\mathrm{T} 1$ & $28.971 b$ & 10.2 & 67.0 & $80.2 \mathrm{bc}$ \\
\hline T4: Delayed trunk shoot removal & $43.486 \mathrm{a}$ & 16.3 & 100.6 & $107.4 \mathrm{ab}$ \\
\hline
\end{tabular}

For each parameter, different letters in the same column indicate significant differences between treatments $(\mathrm{p} \leq 0.05)$

TABLE 3

Stem water potential (MPa) before and after the establishment of treatments 2 and 3, and soil water content (volumetric \%) of the last evaluation, Los Niches-Curicó.

\begin{tabular}{lccccc}
\hline & \multicolumn{3}{c}{ Stem water potential (MPa) } & & $\begin{array}{c}\text { Soil moisture } \\
\mathbf{( \%} \mathbf{\%} / \mathbf{v})\end{array}$ \\
\cline { 2 - 6 } & $\begin{array}{c}\text { January } \\
25 \text { (before } \\
\text { treatments) }\end{array}$ & $\begin{array}{c}\text { January 31 } \\
\text { (1 week after } \\
\text { treatments) }\end{array}$ & $\begin{array}{c}\text { February 23 } \\
\text { (véraison) }\end{array}$ & $\begin{array}{c}\text { March 29 } \\
\text { (first symptoms) }\end{array}$ & $\begin{array}{c}\text { March 29 } \\
\text { (first symptoms) }\end{array}$ \\
\hline T1: Control & $-0.37 \mathrm{a}$ & $-0.44 \mathrm{a}$ & $-0.41 \mathrm{a}$ & $-0.6 \mathrm{a}$ & $26.3 \mathrm{a}$ \\
T2: Defoliation at 50\% of T1 & $-0.4 \mathrm{a}$ & $-0.34 \mathrm{~b}$ & $-0.25 \mathrm{~b}$ & $-0.38 \mathrm{~b}$ & $27.2 \mathrm{a}$ \\
T3: Defoliation at 75\% of T1 & $-0.4 \mathrm{a}$ & $-0.37 \mathrm{~b}$ & $-0.26 \mathrm{~b}$ & $-0.39 \mathrm{~b}$ & $29.4 \mathrm{a}$ \\
T4: Delayed trunk shoot removal & $-0.38 \mathrm{a}$ & $-0.47 \mathrm{a}$ & $-0.42 \mathrm{a}$ & $-0.63 \mathrm{a}$ & $25.5 \mathrm{a}$ \\
\hline
\end{tabular}

For each parameter, different letters in the same column indicate significant differences between treatments $(\mathrm{p} \leq 0.05)$ 


\section{Physicochemical and productive parameters}

Regarding grape physicochemical parameters, the T2 treatment presented higher soluble solids ( ${ }^{\circ}$ Brix) than the $\mathrm{T} 1$ and $\mathrm{T} 4$ treatments (with $100 \% \mathrm{AF}$ ); this was expected due to the smaller surface available for the preparation of photosynthates in the T2 treatment. However, the T3 treatment (with 67\% final effective leaf area) showed no differences in this variable with respect to the control (Table 4). Moreover, no significant differences were found in $\mathrm{pH}$ and titratable acidity among the treatments. In respect to berry productiveness, no statistical differences were observed in the weight of the berries when comparing all the treatments. Furthermore, the T3 treatment presented a greater diameter of the berries than the $\mathrm{T} 1$ and $\mathrm{T} 4$ treatments (Table 5). Based on this, when the atmospheric demand is high, the plants not only extract water from the soil, but also use the water from the berries, which translates into a change in the diameter of the berries and can be irreversible (Creasy \& Lombard, 1993). This supports that fact that the grapevines with a low canopy/root ratio are able to respond better to the evaporative demand of the environment. Pastore et al. (2013) reported that pre-bloom defoliation improved sugar and anthocyanin synthesis, whereas defoliation at véraison had a detrimental effect in terms of less anthocyanin accumulation and a higher incidence of sunburn damage. In addition, Keller et al. (2006) concluded that sugar accumulation in grape berries by apoplastic phloem unloading can reduce xylem water influx into ripening berries. Moreover, it has been reported that xylem flow in ripening berries, but not berry size, remained responsive to root or shoot pressurisation (Keller et al., 2015). A mass balance analysis of ripening berries sampled in the field suggested that phloem water inflow may exceed growth and transpiration water demands (Keller et al., 2015). These considerations indicate that the decrease in xylem inflow at the onset of ripening may be a consequence of the sink-driven increase in phloem inflow (Keller et al., 2015).

\section{Incidence and severity of berry shrinkage}

A lower percentage of grapevines affected by berry shrinkage was observed after T2 and T3 treatments. In addition, the same treatments presented a lower percentage of damaged clusters for the categories of mild to severe and moderate to severe damage, as expected for the trial (Table 6). These results agree with those found by Huguet (1985), who measured lower dehydration of fruit after the defoliation of apple and citrus trees. Delayed trunk shoot removal (T4) did not reduce the leaf area of the shoots, and the canopy/ root ratio was not altered. Moreover, the T4 treatment did not show statistical differences in stem water potential, berry weight, berry diameter, incidence and severity of berry shrinkage compared to the rest of the treatments. Carlomagno et al. (2018) reported that the xylemic backflow is active at pre-véraison but not post-véraison in 'Syrah' grapevines. In addition, these authors showed that there is a 'plant/berry' and 'berry/plant' water communication prevéraison, whereas this seems to cease progressively postvéraison. Moreover, water movement from the berry back to the parent vine via the xylem (backflow) may be an important component of berry weight loss in 'Shiraz', particularly if the phloem ceases functioning at high osmotic potentials near maximum weight (Tyerman et al., 2004). Based on the aforementioned, it would be expected that a more immature berry is less prone to premature dehydration, since its cell membranes have a lower level of damage. As a result of this, the lower incidence and severity of berry shrinkage in the T2 treatment (with a lower concentration of soluble solids) is not only attributable to the effect of the alteration of canopy/

TABLE 4

Soluble solids content $\left({ }^{\circ}\right.$ Brix), $\mathrm{pH}$ and titratable acidity (g/L equivalent of sulfuric acid). Harvest evaluation (2003-05-07), Los Niches-Curicó.

\begin{tabular}{lccc}
\hline Treatments & Soluble solids $\left({ }^{\circ}\right.$ Brix) & pH & Titratable acidity (g/L sulphuric acid) \\
\hline T1: Control & $24.73 \mathrm{a}$ & $3.51 \mathrm{a}$ & $4.66 \mathrm{a}$ \\
T2: Defoliation at 50\% of T1 & $23.07 \mathrm{~b}$ & $3.55 \mathrm{a}$ & $4.74 \mathrm{a}$ \\
T3: Defoliation at 75\% of T1 & $24.23 \mathrm{ab}$ & $3.52 \mathrm{a}$ & $4.56 \mathrm{a}$ \\
T4: Delayed trunk shoot removal & $25.47 \mathrm{a}$ & $3.52 \mathrm{a}$ & $4.43 \mathrm{a}$ \\
\hline
\end{tabular}

For each parameter- different letters in the same column indicate significant differences between treatments $(\mathrm{p} \leq 0.05)$

TABLE 5

Berry weight (g) and diameter (mm), from the last evaluation at harvest (2003-05-07), Los Niches-Curicó.

\begin{tabular}{lcc}
\hline Treatments & Weight of berries $(\mathbf{g})$ & Diameter of berries $(\mathbf{m m})$ \\
\hline T1: Control & $1.44 \mathrm{a}$ & $10.62 \mathrm{a}$ \\
T2: Defoliation at $50 \%$ of T1 & $1.46 \mathrm{a}$ & $11.18 \mathrm{ab}$ \\
T2: Defoliation at $75 \%$ of T1 & $1.53 \mathrm{a}$ & $11.72 \mathrm{~b}$ \\
T4: Delayed trunk shoot removal & $1.38 \mathrm{a}$ & $11.07 \mathrm{a}$ \\
\hline
\end{tabular}

For each parameter, different letters in the same column indicate significant differences between treatments $(\mathrm{p} \leq 0.05)$ 
TABLE 6

Percentage of affected plants (with at least one bunch with moderate and one with severe dehydration) and bunches affected with light damage to severe, or moderate to severe damage. Harvest evaluation (2003-05-07), Los Niches-Curicó.

\begin{tabular}{lccc}
\hline Treatment & \% Affected vines & $\begin{array}{c}\text { \% Affected bunches } \\
\text { (light to severe) }\end{array}$ & $\begin{array}{c}\text { \% Affected bunches } \\
\text { (moderate to severe) }\end{array}$ \\
\hline T1: Control & $62.5 \mathrm{ab}$ & $52.4 \mathrm{a}$ & $24.0 \mathrm{ab}$ \\
T2: Defoliation at $50 \%$ of T1 & $22.9 \mathrm{c}$ & $16.6 \mathrm{~b}$ & $5.2 \mathrm{~b}$ \\
T2: Defoliation at 75\% of T1 & $31.3 \mathrm{bc}$ & $21.2 \mathrm{~b}$ & $3.9 \mathrm{~b}$ \\
T4: Delayed trunk shoot removal & $83.3 \mathrm{a}$ & $65.0 \mathrm{a}$ & $33.9 \mathrm{a}$ \\
\hline
\end{tabular}

For each parameter, different letters in the same column indicate significant differences between treatments $(\mathrm{p} \leq 0.05)$

root ratio, but also to a different physiological condition that means they are not comparable with the rest of the treatments. However, comparing T3 with respect to the T1 and T4 treatments, it was clear that, despite the fact that the grape berries had similar maturity, there was a considerable difference with reference to the incidence and severity of berry shrinkage, which could be attributable to the changes in canopy/root ratio.

The presence of phytoplasma was detected in the samples collected in the two different seasons, which further suggests that this pathogen may be one of the causal agents of the disorder (Matus et al., 2008). It therefore is possible that the presence of these phytoplasmas have an effect on the canopy/root ratio, leading to changes in the aforementioned relationship. Therefore, when bringing the research into connection with the practice, changes in the canopy/root ratio in a commercial vineyard could be both economically and technically unfeasible. Defoliation without previous tests could affect the normal ripening of grapevines, thereby affecting the technological maturity of grape berries. It therefore would be more practicable to try to change the canopy/root ratio by stimulating the development of roots or reducing grapevine vigour in 'Merlot' vineyards. The correction measures will vary depending on the cause of the imbalance between the foliage and root development.

Among the steps that have succeeded in mitigating or solving the berry shrinkage phenomenon in 'Merlot' vineyards it is possible to mention: a) the use of cover crops in order to reduce excessive spring water in the soil as soon as possible after the winter rains, b) the establishment of ridges to increase the volume of soil explored by the roots in the presence of physical impediments, c) the application of organic amendments to stimulate the growth of rootlets in thin or very heavy soils, d) the management of root pests and diseases, e) avoiding over-fertilisation with nitrogen in order to prevent excessive vigour in the spring, and $f$ ) careful planning of irrigation with the aim to avoid large spring growth and periods of stress between véraison and harvest, among others. Despite the aforementioned, the study of changes in the canopy/root ratio must be carried out in more seasons to evaluate the real impact of this form of viticultural management. However, these preliminary results can be useful for 'Merlot' winegrowers in order to mitigate the phenomenon of berry shrinkage .

\section{CONCLUSIONS}

By decreasing the canopy/root ratio, the incidence and severity of berry shrinkage is decreased. Despite the results obtained, more seasons should be studied to evaluate the effects of changes in canopy/root ratio on the incidence and severity of this phenomenon. From a production point of view, the defoliation established in this trial to try to alter the canopy/root ratio is not economically and technically applicable in the vineyard, mainly due to the high economical cost, the lack of practical feasibility and its possible negative effect on grape berry maturation. However, the canopy/ root ratio could be altered by other methods, such as the stimulation of root development and reducing vine vigour. It is particularly important to find a canopy/root ratio that allows the fruit to mature in an appropriate way according to the productive objectives of the wine cellar, while at the same time allowing a reduction in berry shrinkage to levels that are acceptable to the producers.

\section{LITERATURE CITED}

Acevedo-Opazo, C., Valdés-Gómez, H., Taylor, J.A., Avalo, A., VerdugoVásquez, N., Araya, M., Jara-Rojas, F. \& Tisseyre, B., 2013. Assessment of an empirical spatial prediction model of vine water status for irrigation management in a grapevine field. Agric. Water Manag. 124, 58-68.

Bondada, B.R., Matthews, M.A. \& Shackel, K.A., 2005. Functional xylem in the post-veraison grape berry. J. Exp. Bot. 421, 2949-2957.

Carlomagno, A., Novello, V., Ferrandino, A., Genre, A., Lovisolo, C. \& Hunter, J.J., 2018. Pre-harvest berry shrinkage in cv 'Shiraz' (Vitis vinifera L.): Understanding sap flow by means of tracing. Sci. Horti. 233, 394-406.

Chatelet, D.S., Rost, T.L., Matthews, M.A. \& Shackel, K.A., 2008. The peripheral xylem of grapevine (Vitis vinifera) berries. 1. Structural integrity in post-véraison berries. J. Exp. Bot. 59, 1987-1996.

Coombe, B., 1992. Research on development and ripening of the grape berry. Am. J. Enol. Vitic. 43, 101-110.

Creasy, G. \& Lombard, P., 1993. Vine water stress and peduncle girdling effects on pre- and post-veraison grape berry growth and deformability. Am. J. Enol. Vitic. 44, 193-197.

Düring, H., Lang, A. \& Oggionni, F., 1987. Patterns of water flow in Riesling berries in relation to developmental changes in their xylem morphology. Vitis 26, 123-131.

Findlay, N., Oliver, K., Nii, N. \& Coombe, G., 1987. Solute accumulation by grape pericarp cells. J. Exp. Bot. 38, 668-679. 
Huguet, J.G., 1985. Appréciation de l'état hydrique d'une plante à partir des variations micrométriques de la dimension des fruits ou des tiges au tours de la journée. Agronomie 5, 733-741.

Hunter, J. \& Le Roux, D., 1992. The effect of partial defoliation on development and distribution of roots of Vitis vinifera L. cv. Cabernet Sauvignon grafted onto rootstock 99 Richter. Am. J. Enol. Vitic. 43, 71-78.

Kang, S.Z. \& Zhang, J.H., 2004. Controlled alternate partial rootzone irrigation: Its physiological consequences and impact on water use efficiency. J. Exp. Bot. 55, 2437-2446.

Keller, M., Smith, J.P. \& Bondada, B.R., 2006. Ripening grape berries remain hydraulically connected to the shoot. J. Exp. Bot. 57, 2577-2587.

Keller, M., Smithyman, R.P. \& Mills, L.J., 2008. Interactive effects of deficit irrigation and crop load on Cabernet Sauvignon in an arid climate. Am. J. Enol. Vitic. 59, 221-234.

Keller, M., Zhang, Y., Shrestha, P.M., Biondi, M. \& Bondada, B.R., 2015. Sugar demand of ripening grape berries leads to recycling of surplus phloem water via the xylem. Plant Cell Environ. 38, 1048-1059.

Krasnow, M., Matthews, M., Smith, R.J., Benz, M.J., Weber, E. \& Shackel, K., 2010. Distinctive symptoms differentiate four common types of berry shrivel disorder in grape. Calif. Agric. 64, 155-159.

Matthews, M., Anderson, M. \& Schultz, R., 1987. Phenologic and growth responses to early and late season water deficits in Cabernet Franc. Vitis $26,147-160$.

Matus, J.T., Vega, A., Loyola, R., Serrano, C., Cabrera, S. \& Arce-Johnson, P., 2008. Phytoplasma and virus detection in commercial plantings of Vitis vinifera cv. Merlot exhibiting premature berry dehydration. Electron. J. Biotechnol. 11, 5.

McCarthy, M., 1997. The effect of transient water deficit on berry development of cv. Shiraz (Vitis vinifera L.). Aust. J. Grape Wine Res. 3, 102-108.

McCarthy, M. \& Coombe, B., 1999. Is weight loss in ripening grape berries cv. Shiraz caused by impeded phloem transport? Aust. J. Grape Wine Res. $5,17-21$.
McKenry, M., 1984. Grape root phenology relative to control of parasitic nematodes. Am. J. Enol. Vitic. 35, 206-211.

Moreno, Y. \& Vallarino, J., 2011. Manual de consulta de cultivares \& portainjertos de vides para vinificación. Origo editores, Santiago, Chile.

Pastore, C., Zenoni, S., Fasoli, M., Pezzotti, M., Tornielli, G.B. \& Filippetti, I., 2013. Selective defoliation affects plant growth, fruit transcriptional ripening program and flavonoid metabolism in grapevine. BMC Plant Biol. 13,30 .

Reynolds, A., Wardle, D. \& Naylor, A., 1996. Impact of training system, vine spacing, and basal leaf removal on Riesling vine performance, berry composition, canopy microclimate, and vineyard labor requirements. Am. J. Enol. Vitic. 47, 63-76.

Richards, D., 1983. The grape root system. Hort. Rev. 5, 127-159.

Rogiers, S., Keller, M., Holzapfel, B. \& Virgona, J., 2000. Accumulation of potassium and calcium by ripening berries on field vines of Vitis vinifera (L.) cv. Shiraz. Aust. J. Grape Wine Res. 6, 240-243.

Rogiers, S., Smith, J., White, R., Keller, M., Holzapfel, B. \& Virgona, J., 2001. Vascular function in berries of Vitis vinifera (L.) cv. Shiraz. Aust. J. Grape Wine Res. 7, 46-51

Rogiers, S.Y., Greer, D.H., Hatfield, J.M., Orchard, B.A. \& Keller, M., 2006. Solute transport into Shiraz berries during development and lateripening shrinkage. Am. J. Enol. Vitic. 57, 73-80.

Tardieu, F. \& Parent, B., 2017. Predictable ‘meta-mechanisms' emerge from feedbacks between transpiration and plant growth and cannot be simply deduced from short-term mechanisms. Plant Cell Environ. 40, 846-857.

Tyerman, S.D., Tilbrook, J., Pardo, C., Kotula, L., Sullivan, W. \& Steudle, E., 2004. Direct measurement of hydraulic properties in developing berries of Vitis vinifera L. cv. Shiraz and Chardonnay. Aust. J. Grape Wine Res. 10, 170-181.

Van Zyl, J., 1984. Response of Colombard grapevines to irrigation as regards quality aspects and growth. S. Afr. J. Enol. Vitic. 5, 19-28. 